\title{
A FRAGILIDADE DO CONTROLE EXTERNO DAS POLÍCIAS BRASILEIRAS
}

por Analía Soria Batista*

LEMGRUBER, J.; MUSUMECI, L.; CANO, I. Quem vigia os vigias: um estudo sobre controle externo da polícia no Brasil. Rio de Janeiro: Record, 2003. 317 p.

Quem vigia os vigias?... nesta obra, os autores avaliam se os meios atualmente empregados pela sociedade para monitorar a conduta dos políciais civis e militares, do ponto de vista do relacionamento que estabelecem com os cidadãos, estão sendo realmente eficazes. Em extensa pesquisa apontam que, embora existam formalmente no Brasil órgãos encarregados do controle da conduta dos políciais, a eficácia das ações implementadas pode ser amplamente questionada. E, é em função dessa constatação, que são discutidas as razões da distância que existe entre a presença formal desses órgãos e de seus objetivos, e a prática efetiva do controle, identificando os obstáculos existentes e propondo modos de encurtar a distância entre a teoria e a prática do controle externo das polícias.

Os aspectos mais relevantes do estudo residem na abrangência da pesquisa realizada, na utilização de diversas fontes de informação e de dados e na avaliação dos resultados alcançados, articulados à proposta de um novo modelo para o controle externo da polícia no Brasil. Destaca-se pois, o caracter propositivo da obra, que desenha um modo de intervenção na sociedade orientado por pesquisa cuidadosamente realizada.

* Doutora em Sociologia e em Ciências Sociais, pesquisadora associada no NEPEM/ CEAM/ Universidade de Brasília e professora da UNIEURO. 
A preocupação com o controle externo da polícia, baseia-se na constatação de uma realidade onde à violência polícial expressiva corresponde o incremento da desconfiança e do medo da população nos agentes institucionais. Essa situação tem corroído a imagem da corporação junto à sociedade, reforçando, ainda mais, o estigma profissional.

No esforço por interpretar, do ponto de vista de sua historicidade, os desvios dos políciais, os autores recorrem a dois tipos de abordagens. O primeiro, relaciona militarismo e militarização da polícia. Durante o regime militar, a polícia militar teria sido chamada a transformar-se em polícia política, isto é, orientada para a identificação e eliminação dos considerados "enemigos internos"; um modo de relação social baseado na idéia de eliminação do "outro", considerado como diferente/inimigo. Esse ethos profissional tendeu a permanecer durante a democratização do país, embora o "enemigo interno" deixa de ser o comunista, o guerrilheiro, sendo agora produzido como o pobre, o negro, o favelado. Um outro tipo de abordagem apresentada pelos autores, aponta para o papel da polícia como representante do poder repressivo do Estado burguês, e, apesar de estarem cientes do risco de escolher uma análise relativamente simplista do fenômeno da violência polícial, apoiam essa versão, embora sem esquecer que a compreensão aprofundada dos desvios de conduta dos membros da corporação necessita de uma abordagem mais complexa.

É a percepção dessa complexidade que os leva a enfatizar que a diminuição dos desvios comportamentais dos membros da corporação requer um conjunto de estratégias integradas, que abarcam desde a mudança da cultura dessa organização, com especial ênfase nas relações entre os comandantes e os subordinados, a melhoria das condições de trabalho, novas orientações no que diz respeito aos treinamentos e à formação dos servidores, passando pelo controle externo da atividade polícial.

O livro recupera também experiências internacionais consideradas relevantes sobre o controle externo das polícias, mostrando, no entanto, a impossibilidade de discutir modelos de 
controle, pois as experiências relatadas resultam muito heterogêneas. Resta pois "escolher" de maneira seletiva determinados aspectos das experiências internacionais considerados adequados para auxiliar na reestruturação desse controle no pais, estratégia utilizada pelos autores na proposta de um novo modelo para o Brasil.

Foram pesquisados os arquivos das duas entidades (polícia militar e civil) em cinco Estados da Federação e foram entrevistados corregedores, ouvidores, funcionários das ouvidorias, e cidadãos que sofreram violência polícial. A interpelação sistemática de uma diversidade de atores sociais envolvidos nos processos relativos ao controle externo das polícias permite reconstruir a pluralidade de visões sobre os procedimentos utilizados e com relação aos impasses ou dificuldades enfrentadas para levar a cabo essa tarefa.

A corrupção, o extermínio e o abuso de poder são apontados na pesquisa como os crimes mais graves praticados pela polícia, embora o extermínio de suspeitos, pobres e negros tenha se tornado relevante tanto no caso dos políciais militares de São Paulo quanto no caso dos de Rio de Janeiro.

Na pesquisa sobre o controle interno da polícia, tema que também é abordado pelos autores, os próprios Corregedores enfatizam os problemas que os impedem de realizar bem o trabalho, tais como, o volume de trabalho existente, a alta rotatividade das equipes, que dificulta a seqüência das investigações, a falta de equipamento, a falta de treinamento do pessoal que aí trabalha e os problemas relativos à restrição do espaço físico.

Corregedores, delegados e oficiais avaliam que a Corregedoria enfatiza os aspectos investigativos e punitivos, praticamente não investindo na função preventiva/ corretiva. No geral, para os políciais civis e militares, na Corregedoria prevalece a visão punitiva.

Com relação ao controle externo, destaca-se a crítica dos autores à inércia do Ministério Público, que teria entre suas atribuições a realização desse controle, situação que torna ainda mais urgente a eficiência e a eficácia das ações das Ouvidorias. 
No geral, a fiscalização dos políciais e a punição dos maus profissionais ainda enfrenta dificuldades tais que permitem concluir pela fragilidade do controle externo e interno das polícias no Brasil.

Resta assinalar a fecundidade dos resultados da pesquisa, que orientam a elaboração de uma série de recomendações para melhorar a eficiência dos órgãos e a eficácia dos mecanismos de controle existentes. Estas abarcam desde questões mais gerais, como, por exemplo, a necessidade de superar a histórica resistência da polícia ao controle externo, até aspectos pontuais, como melhorias nas estratégias de comunicação das Ouvidorias com a população e a reestruturação de suas rotinas e procedimentos.

Com base nos resultados do estudo realizado e nas experiências internacionais consideradas bem-sucedidas, os autores propõem um novo modelo de controle externo da polícia no Brasil.

É um livro de fundamental importância para os estudiosos e os interessados no tema e para os membros das corporações políciais que permanecem atentos para a necessidade de fortalecer os vínculos positivos com a comunidade, da qual formam parte. 